\title{
Cell Wall Compositional Analysis of Rice Culms
}

Lanjun Zhang ${ }^{1}$, Baocai Zhang ${ }^{1, *}$ and Yihua Zhou ${ }^{1,2, *}$

\author{
${ }^{1}$ State Key Laboratory of Plant Genomics, Institute of Genetics and Developmental Biology, The \\ Innovative Academy of Seed Design, Chinese Academy of Sciences, Beijing, China; ${ }^{2}$ University of \\ Chinese Academy of Sciences, Beijing, China \\ *For correspondence: yhzhou@genetics.ac.cn; bczhang@genetics.ac.cn
}

\begin{abstract}
[Abstract] The plant cell wall is a complicated network that is mainly constituted of polysaccharides, such as cellulose, hemicellulose and pectin. Many noncellulosic polysaccharides are further acetylated, which confers these polymers flexible physicochemical properties. Due to the significance of cell wall in plant growth and development, the analytic platform has been the focus for a long time. Here, we use internodes/culms, an important organ to provide mechanical support for rice plants, as an experimental sample to explore the method for cell wall composition analysis. The method includes preparation of cell wall residues, sequential extraction of polysaccharides, and measurement of cellulose. The procedure for acetate examination is also described. This method is applicable to determine the composition of individual cell wall polymers and the modifier acetates, and is suitable to identify cell wall relevant mutants based on the advantages in high throughput, precision and repeatability.
\end{abstract}

Keywords: Xylan, Pectin, Cellulose, Acetylation, Cell wall, Rice

[Background] The plant cell wall represents one of the most complicated cellular structure in nature and is essential for plant growth and adaptations to environments. Besides presenting multiple polysaccharide components and phenolic compounds, acetylation is a prevalent modification on most cell-wall polymers, which alters the physicochemical properties and increases the complexity of cell wall structure. Establishment of the effective analytic platform for cell wall composition is always a challenging task. The previous analytic method often uses alkali to extract cell wall residues, but removes acetate. Recent works have revealed that acetate patterns on xylan determine the folding of this polymer and impact the binding to cellulose or lignin, indicating its importance in cell wall formation and plant growth control (Grantham et al., 2017; Kang et al., 2019; Zhang et al., 2019). The method that can simultaneously examine the composition of diverse cell-wall polysaccharides and their acetyl modifications needs to be developed. It becomes realizable as solvent dimethyl sulfoxide has been found extracting xylan without trimming acetyl esters (Goncalves et al., 2008). Rice culms are representative for cell wall composition methodology analysis because this organ is rich of secondary wall-bearing fiber cells and also contains multiple cell types. In addition to abundant materials, acetylation level varies on different wall polymers and during the culm development. By using rice culms as analytic samples, we developed a protocol for cell wall composition and acetyl modification analyses with some changes from the previous method (Foster et al., 2010). This protocol offers a widely used way to examine the composition of diverse cell wall polymers and determine the acetate content in 
different rice varieties and other crops.

\section{Materials and Reagents}

1. 96-well flat bottom assay plate (Greiner bio-one, catalog number: 655180)

2. UV capable 96-well flat bottom assay plate (Corning, catalog number: 3635 )

3. Glass bottle

4. Eppendorf tubes (1.5 ml) (Eppendorf, catalog number: 0030120.086)

5. Sarstedt tubes $2 \mathrm{ml}$ (Sarstedt, D-51588)

6. $50 \mathrm{ml}$ plastic centrifuge tube (Corning CentriStar)

7. Glass microfiber filters (Whatman, catalog number: 1820-025)

8. Rice mature plants

9. Endopolygalacturonase M2 (Megazyme, catalog number: PGALUSP, $4{ }^{\circ} \mathrm{C}$ )

10. Pectin methyl esterase (Sigma-Aldrich, catalog number: $\mathrm{P} 5400-1 \mathrm{KU},-20^{\circ} \mathrm{C}$ )

11. $\alpha$-amylase (Megazyme, catalog number: E-BLAAM, $4{ }^{\circ} \mathrm{C}$ )

12. $\mathrm{ddH}_{2} \mathrm{O}$

13. Acetatic Acid Assay Kit (Megazyme, catalog number: K-ACET, $4{ }^{\circ} \mathrm{C}$ )

14. Acetone

15. DMSO (Sigma-Aldrich, catalog number: D5879)

16. $70 \%(\mathrm{v} / \mathrm{v})$ aqueous ethanol

17. Chloroform/methanol $(1: 1, \mathrm{v} / \mathrm{v})$ solution

18. Updegraff reagent (Acetic acid: nitric acid: water, 8:1:2 v/v)

19. $72 \%$ Sulfuric acid (Prepared with concentrated Sulfuric acid GR)

20. $1 \mathrm{mg} / \mathrm{ml}$ glucose stock (Prepared from D-(+)-glucose) (Sigma-Aldrich, catalog number: G8270, $\left.-20^{\circ} \mathrm{C}\right)$

21. Anthrone reagent $(2 \mathrm{mg} / \mathrm{ml}$ Anthrone in concentrated sulfuric acid) (Sigma-Aldrich, catalog number: 319899)

22. Trifluoroacetic acid (TFA) (Sigma-Aldrich, catalog number: T6508)

23. Ammonium formate (Aldrich, catalog number: 516961)

24. $11 \%$ peracetic acid solution (prepared from $35 \%$ peracetic) (Aladdin, catalog number: $\mathrm{P} 112625$ )

25. Ethanol: methanol: water solution (7:2:1, adjust the $\mathrm{pH}$ to 3.0 with $\mathrm{HCOOH})$

26. $1 \%$ ammonium oxalate (Sigma-Aldrich, catalog number: 09898)

27. $37 \%$ hydrogen chloride

28. MES/Tris buffer ( $\mathrm{pH}$ 8.1-8.3) (see Recipes)

29. 2 M trifluoroacetic acid (see Recipes)

30. $1 \mathrm{~N}$ sodium hydroxide (see Recipes)

31. $1 \mathrm{~N}$ hydrogen chloride (see Recipes)

32. $50 \mathrm{mM}$ ammonium formate ( $\mathrm{pH}$ 4.5) (see Recipes) 


\section{Equipment}

1. Freeze dryer (Beijing Songyuanhuaxing Technology Develop Co. Ltd., model: LGJ-12)

2. Ball mill (QIAGEN, TissueLyser II, catalog number: 85300)

3. (Optional) Vortex shaker

4. Basket centrifuge (Eppendorf, model: $5810 \mathrm{R})$

5. Centrifuge (Eppendorf, model: 5430) (to fit Eppendorf $1.5 \mathrm{ml}$ tubes)

6. Thermomixer comfort (Eppendorf)

7. Dri-Block heaters (Techne, model: DB200/3)

8. Microplate reader (PerkinElmer, Enspire)

9. Concentrator (Eppendorf, concentrator plus)

10. (Optional) Drying oven

11. (Optional) Shaking incubator

12. Sieves (Mesh size of $0.15 \mathrm{~mm}$ )

13. $\mathrm{pH}$ meter (Mettler Toledo)

14. Semi-micro scales (dual resolutions starting at $0.01 \mathrm{mg}$ )

\section{Procedure}

A. Preparation of destarched alcohol-insoluble cell-wall residues (AIR)

1. Pool the whole 2 nd internodes (numbered from the top down) of 5-20 rice mature plants.

2. Freeze the fresh samples in liquid nitrogen and then lyophilize them in a freeze dryer (The rice internodes were lyophilized for $48 \mathrm{~h}$ to ensure complete dryness).

3. Grind tissues to a particle size no more than $0.15 \mathrm{~mm}$ using ball mill and sieve through mesh with a size of $0.15 \mathrm{~mm}$.

4. Weigh approximately $1 \mathrm{~g}$ of the ground plant biomass into a $50 \mathrm{ml}$ plastic centrifuge tube.

5. Add $30 \mathrm{ml}$ of $70 \%(\mathrm{v} / \mathrm{v})$ aqueous ethanol, mix thoroughly using a vortex mixer and leave in a thermomixer comfort set at $37^{\circ} \mathrm{C}$ and $200 \mathrm{rpm}$ for $12 \mathrm{~h}$.

6. Centrifuge at $1,500 \times g$ for $10 \mathrm{~min}$ in a basket centrifuge and discard the supernatant.

7. Repeat Steps A5-A6 once.

8. Add $30 \mathrm{ml}$ of the chloroform/methanol $(1: 1 \mathrm{v} / \mathrm{v})$ solution, mix thoroughly using a vortex mixer and leave in a shaking incubator for $30 \mathrm{~min}$ at $37^{\circ} \mathrm{C}$ and $200 \mathrm{rpm}$.

9. Centrifuge at $1,500 \times g$ for $10 \mathrm{~min}$ at room temperature and discard the supernatant.

10. Repeat Steps A8-A9 twice.

11. Add $15 \mathrm{ml}$ of acetone, shake the tube to re-suspend the pellet.

12. Centrifuge at $1,500 \times g$ for $10 \mathrm{~min}$ and discard the supernatant.

13. Repeat Steps A11-A12 twice.

14. Let the biomass samples dry in a drying oven at $40{ }^{\circ} \mathrm{C}$ without shaking for approximately $16 \mathrm{~h}$.

15. Treat the residues with $100 \mathrm{U} \alpha$-amylase in $40 \mathrm{ml} \mathrm{MES} /$ Tris buffer $\left(\mathrm{pH} \mathrm{8.1)}\right.$ at $97^{\circ} \mathrm{C}$ for $35 \mathrm{~min}$, 
then $60{ }^{\circ} \mathrm{C}$ for $1 \mathrm{~h}$.

16. Centrifuge at $1,500 \times g$ for $10 \mathrm{~min}$ and discard the supernatant.

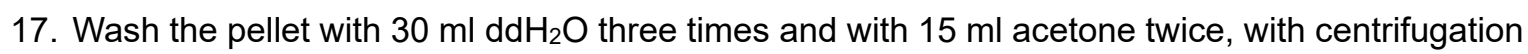
$(1,500 \times \mathrm{g}$ for $10 \mathrm{~min})$ and supernatant removal after each wash.

18. Let the biomass samples dry in an oven at $40^{\circ} \mathrm{C}$ for approximately $16 \mathrm{~h}$ to get destarched AIR.

B. Analysis of the crystalline cellulose content

1. Weigh $2 \mathrm{mg}$ AIR material in five replicates into $2 \mathrm{ml}$ Sarstedt tubes.

2. Add $250 \mu \mathrm{l}$ of $2 \mathrm{M}$ trifluoroacetic acid (TFA) to each sample and make ensure no material is splashed up onto the tube walls.

3. Cap tightly and incubate for $90 \mathrm{~min}$ at $121^{\circ} \mathrm{C}$ in Dri-Block heaters.

4. Cool the heating blocks and samples on ice.

5. Centrifuge at $11,000 \times g$ for $10 \mathrm{~min}$, then transfer the supernatant to a new Sarstedt tube for optional noncellulosic polysaccharides composition analysis (Foster et al., 2010) and keep the pellet for crystalline cellulose assay.

6. Add $1 \mathrm{ml}$ of Updegraff reagent (Acetic acid: itric acid: water, 8:1:2 v/v) to the pellets left over from the Step B5, cap tightly and vortex.

7. Heat in Dri-Block heaters at $100^{\circ} \mathrm{C}$ for $30 \mathrm{~min}$.

8. Cool samples on ice.

9. Centrifuge samples at $11,000 \times \mathrm{g}$ for $10 \mathrm{~min}$.

10. Discard supernatant ensuring no pellet material is discarded.

11. Wash once with $1 \mathrm{ml}$ water and four times with $1 \mathrm{ml}$ acetone, centrifuge and discard supernatant as done above.

12. Air dry the pellet in the Dri-Block heaters at $35^{\circ} \mathrm{C}$.

13. Add $175 \mu \mathrm{l} 72 \%$ Sulfuric acid and incubate at room temperature for $60 \mathrm{~min}$.

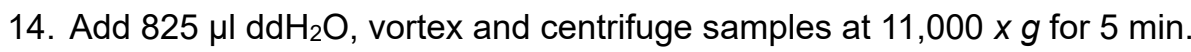

15. Analyze the glucose content of the supernatant using the anthrone assay in a 96-well flat bottom assay plate.

16. Add $10 \mu \mathrm{l}$ of sample and $90 \mu \mathrm{l}$ of $\mathrm{ddH}_{2} \mathrm{O}$ for a total volume of $100 \mu \mathrm{l}$ in each sample well.

17. Prepare standards using $1 \mathrm{mg} / \mathrm{ml}$ glucose stock (stock at $-20^{\circ} \mathrm{C}$ ). Make $0,2,4,6,8$, and $10 \mu \mathrm{g}$ standards by pipetting $0,2,4,6,8$, and $10 \mu$ into the appropriate well, adding $100,98,96,94$, 92, and $90 \mu \mathrm{ldd} \mathrm{H}_{2} \mathrm{O}$ accordingly.

18. Add $200 \mu$ freshly prepared Anthrone Regent.

19. Heat the plate for $30 \mathrm{~min}$ at $80{ }^{\circ} \mathrm{C}$ with shaking in a thermomixer comfort. Cool to room temperature.

20. Shake the plate thoroughly in a thermomixer comfort and then read absorption at $625 \mathrm{~nm}$ within $1 \mathrm{~h}$. 
C. Extraction of pectin from cell wall residues

1. Weigh about $6 \mathrm{mg}$ destarched AIR for 5 replicates into $1.5 \mathrm{ml}$ Eppendorf tubes.

2. Add $1 \mathrm{ml}$ of $50 \mathrm{mM}$ ammonium formate $(\mathrm{pH} 4.5)$ buffer, then add $2 \mathrm{U}$ of endopolygalacturonase $\mathrm{M} 2$ and $0.04 \mathrm{U}$ of pectin methyl esterase. Mix and incubate at $37^{\circ} \mathrm{C}$ for $16 \mathrm{~h}$ with shaking at $300 \mathrm{rpm}$ in a thermomixer comfort.

3. Centrifuge at 3,000 $\times g$ for $10 \mathrm{~min}$ and transfer the pectin-rich supernatants to a new tube. Keep the remains as pectin-free samples.

4. Freeze the supernatants using liquid nitrogen and then lyophilize them in a freeze dryer, finally get the gelatinous pectin.

D. Isolation of the acetyl-xylan from AIR

1. Weigh about $400 \mathrm{mg}$ of destarched AIR into a $50 \mathrm{ml}$ centrifuge tube.

2. Add $30 \mathrm{ml} 1 \%$ ammonium oxalate and incubate at $85^{\circ} \mathrm{C}$ for $2 \mathrm{~h}$. Centrifuge at $1,500 \times \mathrm{g}$ for 15 $\min$ in a basket centrifuge. Discard the supernatant to remove pectin.

3. Add $30 \mathrm{ml} 11 \%$ peracetic acid solution, incubate in a water bath at $85{ }^{\circ} \mathrm{C}$ for $30 \mathrm{~min}$ for delignification.

4. Centrifuge at $1,500 \times g$ for $10 \mathrm{~min}$. Discard the supernatant and wash the pellets with $30 \mathrm{ml}$ $\mathrm{dd}_{2} \mathrm{O}$ three times and with $15 \mathrm{ml}$ acetone once, through centrifugation $(1,500 \times \mathrm{g}$ for $10 \mathrm{~min})$ and supernatant removal.

5. Let the pellets dry in an oven set at $40^{\circ} \mathrm{C}$ for approximately $16 \mathrm{~h}$.

6. Add $30 \mathrm{ml}$ DMSO and then incubate at $70^{\circ} \mathrm{C}$ for $12 \mathrm{~h}$ to conduct extraction, centrifuge at 1,500 $x \mathrm{~g}$ for $10 \mathrm{~min}$, transfer the supernatant to a new glass bottle.

7. Repeat Step D6 with $12 \mathrm{ml}$ DMSO, and combine the supernatants containing the extractives.

8. Filter the extracts through glass microfiber filters.

9. Precipitate the extracts with 5 volume of ethanol: methanol: water solution $(7: 2: 1, \mathrm{pH} 3.0)$ at $4{ }^{\circ} \mathrm{C}$ for $12 \mathrm{~h}$.

10. Centrifuge at $1,500 \times g$ for $15 \mathrm{~min}$. Discard the supernatant and wash the pellets four times each with $10 \mathrm{ml}$ anhydrous ethanol with centrifugation $(1,500 \times \mathrm{g}$ for $10 \mathrm{~min})$ and supernatant removal after each wash.

11. Dry the pellets under vacuum in a concentrator at room temperature.

E. Determining the content of acetyl esters

1. Weigh about $1 \mathrm{mg}$ destarched AIRs/pectin/xylan for 5 replicates into $1.5 \mathrm{ml}$ Eppendorf tubes.

2. Add $100 \mu \mathrm{l} 1 \mathrm{~N}$ sodium hydroxide to tubes and shake for $1 \mathrm{~h}$ at $28^{\circ} \mathrm{C}$ and $200 \mathrm{rpm}$ to release the bound acetate.

3. Add $100 \mu \mathrm{l}$ of $1 \mathrm{~N}$ hydrogen chloride to neutralize samples.

4. Centrifuge at $15,000 \times g$ for $10 \mathrm{~min}$, and transfer $10 \mu$ supernatant aliquot to a UV capable 96well flat bottom assay plate and immediately quantify released acetic acids according to the instruction of Acetic Acid Assay Kit. 
5. Add $94 \mu \mathrm{l}$ of $\mathrm{ddH}_{2} \mathrm{O}$ to each sample well in the UV capable 96-well flat bottom assay plate.

6. Add $42 \mu \mathrm{l}$ of freshly prepared mixture of kit-supplied Solutions 1 and $2(2.5: 1,30 \mu \mathrm{l}+12 \mu \mathrm{l}$ each), mix and incubate at $25^{\circ} \mathrm{C}$ for $3 \mathrm{~min}$ with shaking at $300 \mathrm{rpm}$ in a thermomixer comfort.

7. Read the absorption at $340 \mathrm{~nm}(\mathrm{~A} 0)$.

8. Add $12 \mu \mathrm{l}$ of freshly diluted kit-supplied solution $3\left(1: 10, \mathrm{v} / \mathrm{v}\right.$, in $\left.\mathrm{ddH}_{2} \mathrm{O}\right)$, mix and incubate at $25{ }^{\circ} \mathrm{C}$ for 4 min with shaking at $300 \mathrm{rpm}$ in a thermomixer comfort.

9. Read the absorption at $340 \mathrm{~nm}(\mathrm{~A} 1)$.

10. Add $12 \mu \mathrm{l}$ of freshly diluted kit-supplied solution $4\left(1: 10, \mathrm{v} / \mathrm{v}\right.$, in $\left.\mathrm{ddH}_{2} \mathrm{O}\right)$, mix and incubate at $25^{\circ} \mathrm{C}$ for 12 min with shaking at $300 \mathrm{rpm}$ in a thermomixer comfort.

11. Read the absorption at $340 \mathrm{~nm}(\mathrm{~A} 2)$.

12. At the same time, it is necessary to make a blank control and a standard curve in parallel. To make a standard curve, add $5,10,15,30,50 \mu \mathrm{l}$ acetic acid standard (solution 5 ) equal to 0.5 , $1,1.5,3,5 \mu \mathrm{g}$, and adjust the volume of $\mathrm{ddH}_{2} \mathrm{O}$ in Step $\mathrm{E} 5$ to $99,94,89,74,54 \mu \mathrm{l}$, respectively.

\section{Data analysis}

1. Generation of standard curve and calculation of cellulose content

To calculate cellulose amount, the standard curve needs to be plotted out first (The absorbance of glucose standards versus the concentration of glucose standards). Then calculate cellulose content ( $\mu \mathrm{g}$ glucose/mg AIR) of sample with standard curve.

2. For acetylation content analysis: $\Delta$ acetic acid $=(\mathrm{A} 2-\mathrm{A} 0)_{\text {sample }}-(\mathrm{A} 1-\mathrm{A} 0)^{2}$ sample $/(\mathrm{A} 2-\mathrm{A} 0)_{\text {sample }}$ [(A2-A0)blank - (A1 - A0)²blank/(A2 - A0)blank].

Locate the sample value in the standard curve, and get acetic acid content in the sample aliquot. Calculate sample contents by multiplying with a factor of $(100+100) / 10 /$ weight $(\mu \mathrm{g} / \mathrm{mg} \mathrm{AIR})$.

3. For statistical analysis, typically use at least five biological replicates from a pool of internodes. Results are reported as means and standard deviation and statistical significance is assessed by Student's $t$-test or one-way ANOVA followed by Tukey's multiple comparison test.

\section{$\underline{\text { Notes }}$}

1. If a freeze-dryer is not available, it could be alternative to prepare AIR directly from frozen tissue that is homogenized with a mortar and pestle immersed in liquid nitrogen or a ball mill preimmersed in liquid nitrogen.

2. For acetylation analysis, the acetic acid released should be assayed as soon as possible, do not leave too long before plate reading.

\section{Recipes}

1. MES/Tris buffer ( $\mathrm{pH} 8.1)$ 
a. Add $488 \mathrm{mg} \mathrm{MES}$ and $355 \mathrm{mg}$ Tris in $40 \mathrm{ml}$ double distilled water

b. Adjust the $\mathrm{pH}$ to 8.1 with sodium hydroxide and finally dilute to $50 \mathrm{ml}$

2. $2 \mathrm{M}$ trifluoroacetic acid

Dilute $15.31 \mathrm{ml}$ TFA with $\mathrm{ddH}_{2} \mathrm{O}$ to a final volume of $100 \mathrm{ml}$

3. $1 \mathrm{~N}$ sodium hydroxide

Add $2 \mathrm{~g}$ of sodium hydroxide to $50 \mathrm{ml}$ of $\mathrm{ddH}_{2} \mathrm{O}$

4. $1 \mathrm{~N}$ hydrogen chloride

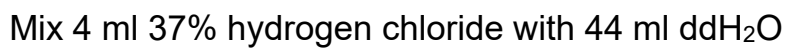

5. $50 \mathrm{mM}$ ammonium formate $(\mathrm{pH} 4.5)$

a. Add $0.15 \mathrm{~g}$ of ammonium formate to $50 \mathrm{ml} \mathrm{ddH}_{2} \mathrm{O}$

b. Adjust the $\mathrm{pH}$ to 4.5 with formic acid

\section{Acknowledgments}

This protocol was adapted from previous work (Zhang et al., 2019). This work was supported by the National Natural Science Foundation of China (grant No. 31530051, 31571247, and 91735303), the Youth Innovation Promotion Association, Chinese Academy of Sciences (grant No. 2016094). This protocol is based on the following previously published reports: Updegraff (1969), Harholt et al. (2006), Goncalves et al. (2008), Li et al. (2009), Foster et al. (2010), Bromley et al. (2013), de Souza et al. (2014), Zhang et al. (2017).

\section{Competing interests}

The authors declare no conflict of interest.

\section{$\underline{\text { References }}$}

1. Bromley, J. R., Busse-Wicher, M., Tryfona, T., Mortimer, J. C., Zhang, Z., Brown, D. M. and Dupree, P. (2013). GUX1 and GUX2 glucuronyltransferases decorate distinct domains of glucuronoxylan with different substitution patterns. Plant J 74(3): 423-434.

2. de Souza, A., Hull, P. A., Gille, S. and Pauly, M. (2014). Identification and functional characterization of the distinct plant pectin esterases PAE8 and PAE9 and their deletion mutants. Planta 240(5): 1123-1138.

3. Goncalves, V. M., Evtuguin, D. V. and Domingues, M. R. (2008). Structural characterization of the acetylated heteroxylan from the natural hybrid Paulownia elongatalPaulownia fortunei. Carbohydr Res 343(2): 256-266.

4. Foster, C.E., Martin, T.M., Pauly, M. (2010). Comprehensive compositional analysis of plant cell walls (Lignocellulosic biomass): Part II. Carbohydrates. J Vis Exp 37: e1837.

5. Grantham, N. J., Wurman-Rodrich, J., Terrett, O. M., Lyczakowski, J. J., Stott, K., luga, D., 
Simmons, T. J., Durand-Tardif, M., Brown, S. P., Dupree, R., Busse-Wicher, M. and Dupree, P. (2017). An even pattern of xylan substitution is critical for interaction with cellulose in plant cell walls. Nat Plants 3(11): 859-865.

6. Harholt, J., Jensen, J. K., Sorensen, S. O., Orfila, C., Pauly, M. and Scheller, H. V. (2006). ARABINAN DEFICIENT 1 is a putative arabinosyltransferase involved in biosynthesis of pectic arabinan in Arabidopsis. Plant Physiol 140(1): 49-58.

7. Kang, X., Kirui, A., Dickwella Widanage, M. C., Mentink-Vigier, F., Cosgrove, D. J. and Wang, T. (2019). Lignin-polysaccharide interactions in plant secondary cell walls revealed by solidstate NMR. Nat Commun 10(1): 347.

8. Li, M., Xiong, G., Li, R., Cui, J., Tang, D., Zhang, B., Pauly, M., Cheng, Z. and Zhou, Y. (2009). Rice cellulose synthase-like D4 is essential for normal cell-wall biosynthesis and plant growth. Plant J 60(6): 1055-1069.

9. Updegraff, D. M. (1969). Semimicro determination of cellulose in biological materials. Anal Biochem 32(3): 420-424.

10. Zhang, B., Zhang, L., Li, F., Zhang, D., Liu, X., Wang, H., Xu, Z., Chu, C. and Zhou, Y. (2017). Control of secondary cell wall patterning involves xylan deacetylation by a GDSL esterase. Nat Plants 3: 17017.

11. Zhang, L., Gao, C., Mentink-Vigier, F., Tang, L., Zhang, D., Wang, S., Cao, S., Xu, Z., Liu, X., Wang, T., Zhou, Y. and Zhang, B. (2019). Arabinosyl deacetylase modulates the Arabinoxylan acetylation profile and secondary wall formation. Plant Cell 31(5): 1113-1126. 